\begin{tabular}{ccc}
\hline & $\begin{array}{c}\text { International Journal of Health Services } \\
\text { Research and Policy } \\
\text { www.dergipark.org.tr/ijhsrp }\end{array}$ \\
$\begin{array}{c}\text { INTESEG } \\
\text { ENGINETIONAL } \\
\text { SCIENCE AND } \\
\text { EDUCATION GROUP }\end{array}$ & e-ISSN: 2602-3482 & IJHSRP \\
\hline
\end{tabular}

Research Article

\title{
EVALUATION OF SLEEP QUALITY WITH BURNOUT LEVEL IN EMERGENCY MEDICAL ASSISTANTS
}

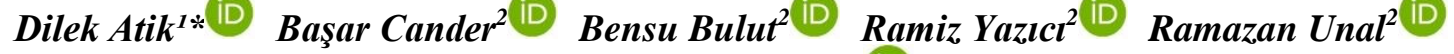 \\ Hasan Burak Kaya ${ }^{1}$ iD \\ ${ }^{1}$ Department of Emergency Medicine, Yozgat Bozok University, Yozgat, TURKEY \\ ${ }^{2}$ Department of Emergency Medicine, University of Health Sciences Kanuni Sultan Suleyman Research and \\ Training Hospital, İstanbul, TURKEY \\ *Corresponding Author: dr.dilekgok82@hotmail.com
}

\begin{abstract}
Burnout syndrome is a condition in which people work in professions that require face-toface communication and prolonged stress and personal copying methods fail. Healthcare professionals are one of the riskiest occupational groups in terms of burnout syndrome due to their heavy workload. Intense and stressful conditions reduce the joy and productivity of healthcare professionals. In this study, our primary aim is to evaluate the relationship between burnout level and sleep quality in emergency medicine assistants (EMA). This study is a descriptive and cross-sectional study. According to the data obtained from the Higher Education Board, the personal information form and Maslach Burnout Inventory (MBI) and Pittsburgh Sleep Quality Index (PSQI) surveys were sent to all emergency assistants receiving training in Turkey. A total of 94 people working as emergency medical assistants participated in our study. According to the MBI subgroup emotional exhaustion, 84\% $(n=79)$ of the participants had a high level of emotional exhaustion and $16 \%(15)$ had moderate emotional exhaustion. When the MBI subgroup desensitization was evaluated, $87.2 \%(n=82)$ was found high and $12.8 \%(n=$ 12) was found moderate. When the personal success of the MBI subgroup was evaluated, $97.9 \%$ ( $n=$ 92) was found low and $2.1 \%(n=2)$ was found moderate. When the correlation between the MBI subgroups and the PSQI scoring was evaluated, a moderate positive correlation was found between emotional exhaustion and PSQI ( $p \leq 0.001)$. When the sleep quality with MBI is evaluated by regression analysis, it is seen that the state of exhaustion affects the quality of sleep by 13.1\%. A high level of burnout during the education period of the emergency medicine assistant causes sleep quality deterioration. This situation causes difficulties in business and private life over time. We think that it will be beneficial to regulate the monthly working hours in order to decrease the burnout levels and increase sleep quality for keeping EMAs physically and mentally healthy, to increase the training staff to make them feel safe, and to organize programs to increase non-work social activities.
\end{abstract}

Keywords: Maslach Burnout Inventory, Sleep Quality, Emergency Medical Assistants

Received: April 1, $2020 \quad$ Accepted: May 29, 2020

\section{Introduction}

Burnout syndrome is a condition in which people work in professions that require face-to-face communication and prolonged stress and personal coping methods fail [1]. The concept of burnout, which was defined for the first time in 1974, was defined as emotional exhaustion due to the inability to fulfill their occupational requirements as a result of long working hours [2]. Healthcare professionals are one of the riskiest occupational groups in terms of burnout syndrome due to their heavy workload. 
Intense and stressful conditions reduce the joy and productivity of healthcare professionals [3]. In addition to the workload, the need to provide emotional support, providing care for severe and deadly patients, disturbed sleep patterns, and the high number of duties increase burnout in major stressors on healthcare professionals [4,5]. In addition to the stressful environment in the workplace, an irregular social life prepares the ground for the burnout of Emergency personnel over time [6].

Sleep is one of the basic requirements and it should be regular so that people can be healthy physically and mentally [7, 8]. Sleep helps the body rest and enable correction and repair of brain functions. The quality of sleep, which is an important aspect of this biological process that provides body renewal, is that the individual feels fit and fit after awakening [9]. The circadian rhythm is the cycle in which the human body actively continues its vital activities during the 24-hour day in the period of sunlight, and passes to sleep rhythm more passively after sunset. Disruption of this rhythm leads to poor quality of sleep and sleep disorders [10]. Inadequate sleep resulting from the working patterns and departments of healthcare professionals causes sleep disorders [11, 12].

According to two different studies by Maslach et al. on burnout syndrome, there are three main factors related to this syndrome. These are divided into three sub-categories as emotional burnout, desensitization, and personal accomplishment $[2,13]$. Working with a shift and duty systems may cause physiological and/or psychological health problems after a while as it contradicts the biological rhythm of the person $[13,14]$. In the literature, it has been reported in studies related to nurses that the state of burnout arising from the disruption of the circadian rhythm increases $[15,16]$.

Sleep rhythm and sleep quality are seen in normal people deteriorate due to the working patterns with shifts and duties $[17,18,19]$. The duration of the emergency medicine assistantship training is 4 years, and it is a difficult process. During this period, it causes sleep disorders. In this study, our primary aim is to evaluate the relationship between burnout level and sleep quality in emergency medical assistants.

\section{Method}

\subsection{Study Design}

This study is a descriptive and cross-sectional study. Approval was obtained from the local ethics committee for the study. Our study was conducted between 1.12.2019-31.12.2019. According to the data obtained from the Higher Education Board, the personal information form and Maslach Burnout Inventory (MBI) and Pittsburgh Sleep Quality Index (PSQI) surveys were delivered to all emergency assistants who receive training in Turkey. The questionnaire forms were sent via e-mail. According to the data obtained from the Higher Education Information system, the universe of the study was determined as 705 emergency medical assistants [20]. Power analysis was applied to determine the appropriate sample size. Accordingly, the sample size of this study was calculated to be 83 individuals with an effect of 0.50 , a power of $85 \%$, and an error of $0.05 \alpha$. Participants who received emergency medicine training were included in the study. A total of 94 people working as emergency medical assistants participated in our study. Participants were grouped according to age, marital status, sex, number of children, year of assistantship, occupational year, monthly working hours, educational staff, type of hospital worked, and number of patients applying to the emergency department.

Ethics declaration: This study was approved by the Ethics Committee of Yozgat Bozok University on 30.10.2019 with the decision of 2017-KAEK-189_2919.189.10.30_24. Our study was carried out in 
accordance with the Helsinki Declaration. The study is voluntary and permission has been obtained from the participants.

\subsection{Scales Used}

\subsubsection{Maslach Burnout Inventory (MBI)}

Maslach Burnout Inventory was created by Maslach and Jackson and consists of 22 items. The inventory has sub-dimensions of emotional exhaustion, personal success, and desensitization. Emotional exhaustion is defined as the feeling of being overloaded and depleted due to the work of the person. Desensitization is a situation related to the attitude and behavior of the person devoid of emotion towards their care and service. Personal success, on the other hand, is defined as overcoming the problems and finding oneself self-sufficient [21]. It was adapted to Turkish by Ergin in 1992. He arranged the answers to the questions in a 5-point likert in accordance with the Turkish society [22]. 5-point scale $(0=$ never, $1=$ very rarely, $2=$ sometimes, $3=$ usually, $4=$ always) was shaped according to Turkish culture.

Scoring between 0 and 16 from the emotional burnout subscale indicates low burnout, scoring between 17 and 26 indicates moderate burnout, and scoring 27 and above indicates high burnout. Scoring 0-6 from the burnout subscale of desensitization indicates low burnout, scoring 7-12 indicates moderate and scoring 13 and higher indicates high burnout. Scoring 39 and above from the burnout subscale in the form of personal success indicates low burnout, scoring between 32-38 points indicates moderate, and scoring up to 0-31 points shows high levels of burnout. In our study, the reliability coefficient of the MBI was calculated with Cronbach Alpha and was found 0.775.

\subsubsection{Pittsburgh Sleep Quality Index (PSQI)}

PSQI was developed by Buysse et al. (1989) and has been shown to have sufficient internal consistency $($ Cronbach's alpha $=0.80$ ), test-retest reliability and validity $[23,24]$. The validity and reliability study of PSQI in our country was performed by Ağargün et al. (1996) (Cronbach's alpha = 0.80) [24]. PSQI consists of 7 components: subjective sleep quality (component 1), sleep latency (component 2), sleep time (component 3), habitual sleep efficiency (component 4), sleep disorder (component 5), use of sleeping medicine (component 6) and daytime dysfunction (component 7). The sum of the seven component points gives the total PSQI score. The response of each is scored between 0-3 according to the frequency of the symptoms. The scale has a total score between 0-21. A total scale score between 0-4 points indicates good sleep quality, and between 5-21 points means bad sleep quality. In our study, the reliability coefficient of the PSQI was calculated with Cronbach's Alpha and was found at 0.76 .

\subsubsection{Statistical Analysis}

All statistical data were analyzed by SPSS 20.0 for Windows. Kolmogorov-Smirnov test and skewness-kurtosis method were used to evaluate the normal distribution of all variables. In addition, the normal distribution of the data was evaluated with the histogram as one of the graphical methods. Descriptive statistics were used in the demographic examination of the patients. When evaluating the data in the study, the Chi-square test was applied if it was qualitative. In the evaluation of the study data, numerical values are expressed as mean \pm standard deviation. In the comparison of the numerical 
changes between variables that are statistically parametric and the data obtained by the study carried out within the scope of clinical research, student's t-test and non-parametric characteristics, according to the categorical (nominal or ordinal), numerical independent group of the established variables, KruskalWallis $\mathrm{H}$ test, and Mann-Whitney U test was used. For correlations between data, the Pearson rank correlation method was used in parametric data and Spearman rank correlation method was used in nonparametric data. The linear regression method was used to evaluate the effect of sleep quality on MBI subgroups. A p value less than 0.05 has been accepted statistically significant.

\section{Results}

A total of 94 people working as emergency medical assistants participated in our study. The mean age of the male participants in the study was $29.08 \pm 3.03$, and the mean age of the female participants was $29.2 \pm 3.4$. There was no statistically significant difference between the mean ages of the participants $(\mathrm{t}:-0.006 ; \mathrm{p}=0.513) .59 .1 \%(\mathrm{n}=59)$ of the participants were male and $40.9 \%(\mathrm{n}=35)$ were female. The sex difference of the participants was found to be statistically significant $\left(x^{2}: 49.809\right.$; $\mathrm{p} \leq 0.001)$. According to the marital status of the participants, $64.9 \%(\mathrm{n}=61)$ were married and $35.1 \%$ $(\mathrm{n}=33)$ were single. When the number of children of the participants was evaluated, $60.6 \%(\mathrm{n}=57)$ had 0 children, $37.3 \%(n=35)$ had 1 child, $2.1 \%(n=2) 2$ or more children.

When the monthly working hours of the participants were evaluated, $44.7 \%(\mathrm{n}=41)$ reported that they worked 241 hours or more, $30.9 \%(n=29) 217-240$ hours, $17 \%(n=16) 193-216$ hours, $7.4 \%$ $(\mathrm{n}=7) 192$ and below. When the participants' years of work in the profession were evaluated, $54.7 \%(\mathrm{n}=$ 54) had been working 0-4 years, $29.8 \%(\mathrm{n}=28) 5-9$ years, and $12.8 \%(\mathrm{n}=12) 10-14$ years. When the emergency assistantship period of the participants was evaluated, $37.2 \%(\mathrm{n}=35)$ were first year assistants, $23.4 \%(\mathrm{n}=22)$ second year assistants, $18.1 \%(\mathrm{n}=17)$ were third year assistants, and $21.3 \%$ $(\mathrm{n}=20)$ were fourth year assistants.

When the number of monthly patient admissions in the places where the participants work is evaluated, 42.6\% $(n=40)$ had 500-1000, 20.2\% $(n=19)$ had 250-500, 16.2\% $(n=15)$ had 100-249, 9.6\% $(\mathrm{n}=9)$ had 1000-1500, 9.6\% $(\mathrm{n}=9)$ had 1501-2000, 2.1\% $(\mathrm{n}=2)$ had 50-100 patient admissions. When the types of hospital the participants worked at were evaluated, $51.1 \%(n=48)$ were employed at Education Research Hospital (ERH), 48.9\% $(n=46)$ in the university hospital. There was no statistically significant difference according to the hospital type of the participants ( 2 2: 0.043, $\mathrm{p}=0.837)$.

According to the MBI subgroup emotional exhaustion, $84 \%(n=79)$ of the participants had a high level of emotional exhaustion and 16\% (15) had moderate emotional exhaustion. When the MBI subgroup desensitization was evaluated, $87.2 \%(n=82)$ was found high and $12.8 \%(n=12)$ was found moderate. When the personal success of the MBI subgroup was evaluated, 97.9\% ( $n=92)$ was found low and $2.1 \%(n=2)$ was found moderate. When the whole MBI was evaluated, 92.6\% ( $n=87)$ were found at a high, and $7.4 \%(\mathrm{n}=7)$ at a moderate level. The mean scores of emotional exhaustion scores of the participants were $31.8 \pm 5.07$, the desensitization of the subgroups was $17.9 \pm 3.7$, and the mean score of personal achievement was $24.5 \pm 3.6$.

When the MBI subgroup scores were compared according to the demographic characteristics of the participants, no significant relationship was found between age groups, sex, and the sub-dimensions of the MBI ( $p>0.005)$ (Table 1). 
When the marital status of the participants was evaluated in the MBI, no statistically significant difference was found in the emotional exhaustion subgroup ( $p>0.05$ ). A statistically significant difference was found between marital status groups in desensitization and personal success among the subgroups of MBI ( $p=0.044 ; p=0.032)$. When the MBI was evaluated according to the number of children of the participants, a statistically significant difference was found in desensitization and personal achievement subgroup $(\mathrm{p}=0.048 ; \mathrm{p}=0.049)($ Table 1$)$.

Table 1. Socio-demographic data of the participants and distribution of MBI subgroups

\begin{tabular}{|c|c|c|c|c|c|}
\hline Groups & & Percent/N & EE $($ Mean \pm Sd $)$ & DS(Mean \pm Sd) & $\operatorname{PS}($ Mean \pm Sd) \\
\hline \multirow[t]{4}{*}{ Age groups } & $24-25$ age & $\% 8.5(8)$ & $29.5 \pm 2.8$ & $18.4 \pm 4.4$ & $22.3 \pm 3.2$ \\
\hline & $26-27$ age & $\% 25.5(25)$ & $32.7 \pm 4.6$ & $17.3 \pm 3.9$ & $25 \pm 3.4$ \\
\hline & $28-29$ age & $\% 30.9(29)$ & $32.3 \pm 4.5$ & $17.7 \pm 3.7$ & $24.3 \pm 3.5$ \\
\hline & 30 and older & $\% 35.1(33)$ & $31.3 \pm 6$ & $18.6 \pm 3.3$ & $24.8 \pm 3.9$ \\
\hline \multicolumn{3}{|l|}{ K.W.H. T(p value) } & $0.282^{\mathbf{b}}$ & $0.407^{\mathbf{b}}$ & $0.356^{\mathbf{b}}$ \\
\hline \multirow[t]{2}{*}{ Gender } & Female & $\% 40.9(35)$ & $31.6 \pm 5.1$ & $17.08 \pm 3.2$ & $24.9 \pm 3.8$ \\
\hline & Male & $\% 59.1(59)$ & $32.01 \pm 5.09$ & $18.01 \pm 4.04$ & $24.3 \pm 3.4$ \\
\hline \multicolumn{3}{|l|}{ M.W. U.T(p-value) } & $0.376^{\mathbf{b}}$ & $0.365^{\mathbf{b}}$ & $0.562^{b}$ \\
\hline \multirow[t]{2}{*}{ Marital Status } & Married & $\% 64.9(61)$ & $31.5 \pm 5.2$ & $17.3 \pm 3.6$ & $24 \pm 3.4$ \\
\hline & Single & $\% 35.1(33)$ & $32.4 \pm 4.8$ & $19 \pm 3.7$ & $25.6 \pm 3.8$ \\
\hline \multicolumn{3}{|l|}{ M.W. U.T(p-value) } & $0.597^{\mathbf{b}}$ & $0.044^{\mathrm{a}}$ & $0.032^{\mathrm{a}}$ \\
\hline \multirow[t]{3}{*}{ Number of children } & 0 child & $\% 60.6(57)$ & $32.7 \pm 4.6$ & $18.6 \pm 3.6$ & $25.3 \pm 3.4$ \\
\hline & 1 child & $\% 37.3(35)$ & $30.8 \pm 5.2$ & $16.9 \pm 3.6$ & $23.4 \pm 3.6$ \\
\hline & 2 children & $\% 2.1(2)$ & $26 \pm 8.4$ & $17 \pm 5.6$ & $23 \pm 1.4$ \\
\hline \multicolumn{3}{|l|}{ K.W.H.T(p-value) } & $0.137^{\mathbf{b}}$ & $0.048^{\mathrm{a}}$ & $0.049^{\mathrm{a}}$ \\
\hline \multicolumn{6}{|c|}{$\begin{array}{l}\text { K.W.H.T.= Kruskal Wallis H Test, M.W. U.T=Mann-Whitney U Test,EE=Emotional Exhaustion,DS= } \\
\text { Desensitization,PS=Personal Success "a" =significance level of } p<0.05, " b "=>0.05 \text { is not significant. }\end{array}$} \\
\hline
\end{tabular}

As shown in Table 2, when the MBI was evaluated according to the monthly working hours of the participants, a statistically significant difference was found in the subgroups of emotional exhaustion, desensitization and personal success ( $\mathrm{p}<0.05$ ) (Table 3). When the subgroups of MBI were evaluated according to the participants' year of assistantship, there was no statistically significant relationship between the groups ( $p>0.05$ ). Although there was a statistically significant difference in emotional exhaustion among the subgroups of the MBI according to the participants' year of work ( $\mathrm{p}=$ 0.041), there was no statistically significant difference in the desensitization and personal success subgroups ( $\mathrm{p}>0.05)$. (Table 2). 
Table 2. Distribution of MBI subgroups according to the study variables of the participants

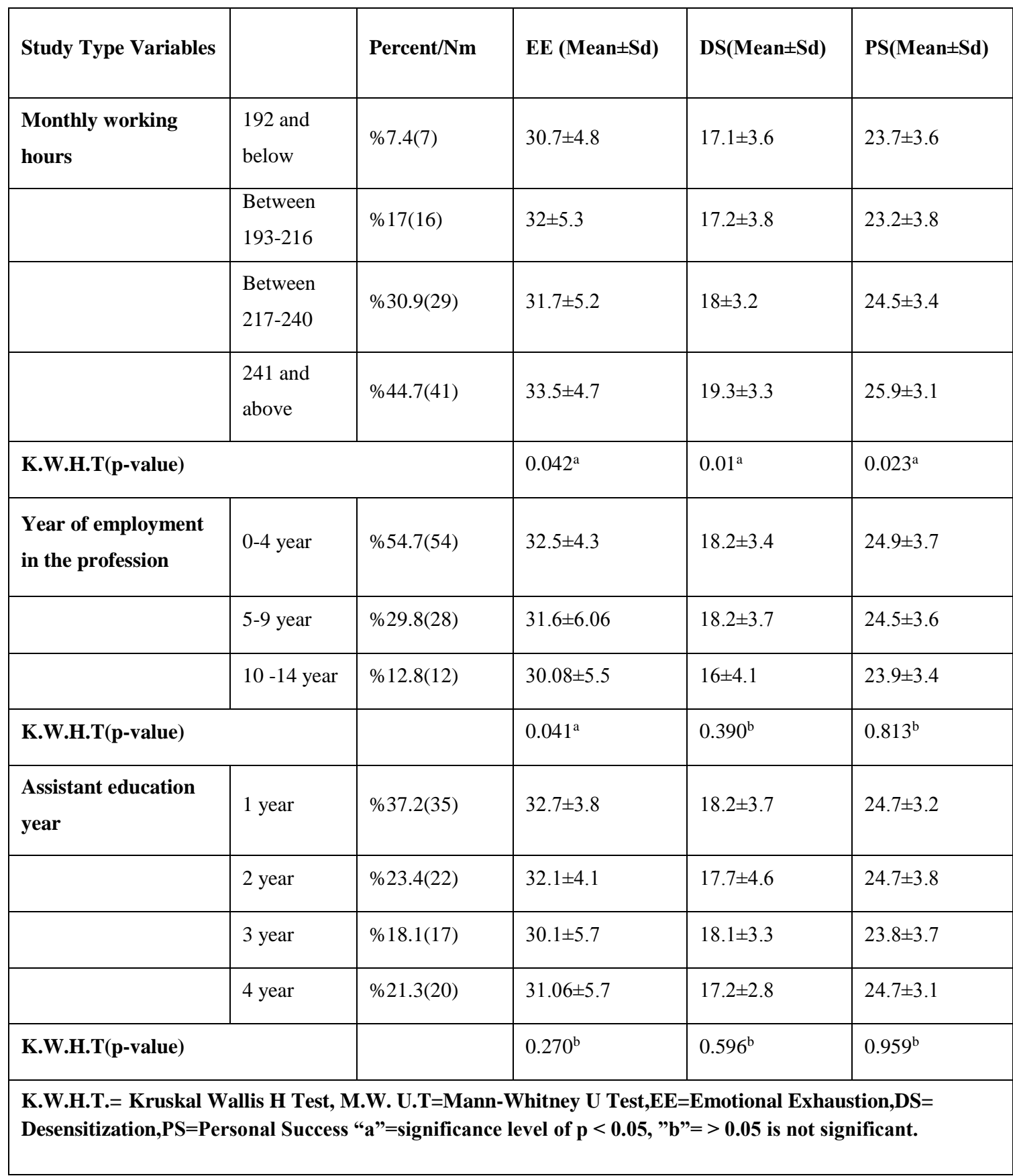

When the subgroups of MBI were evaluated according to the hospital where the participants in the study worked, there was no statistically significant relationship in all three subgroups ( $p>0.05$ ) (Table 3). There was no statistically significant difference in the number of patients entering the emergency department in the hospitals where (emergency medicine assistant) EMAs participated in the study ( $\mathrm{P}>0.05)$. When the MBI subgroups of the participants in the study were evaluated according to the teaching staff, there was a statistically significant difference in the desensitization and personal success subgroups $(p<0.05)$. No statistically significant difference was found in the emotional exhaustion subgroup ( $\mathrm{p}>0.05)$ (Table 3$)$. 
When the correlations of the MBI subgroups according to the year of employment and monthly working hours are evaluated, there was a moderate negative relationship between the year of work in the profession and emotional exhaustion ( $\mathrm{r}: 0.560 ; \mathrm{p}=0.040$ ). There was no positive or negative correlation between the year of work in the profession and the desensitization and personal success among the MBI subgroups ( $p>0.05$ ). A moderate positive correlation was found between monthly working hours and emotional exhaustion ( $\mathrm{r}: 0.429 ; \mathrm{p}=0.011$ ). A moderately significant positive correlation was found with desensitization among subgroups $(\mathrm{r}: 0.321 ; \mathrm{p} \leq 0.01)$. A moderate negative correlation was found between personal success and monthly work $(r:-0.315 ; p=0.02)$.

Table 3. Hospital Characteristics of the Participants and the relationship between MBI subgroups

\begin{tabular}{|c|c|c|c|c|c|}
\hline \multicolumn{3}{|c|}{ Hospital Characteristics } & EE $($ Mean \pm Sd $)$ & $\operatorname{DS}($ Mean \pm Sd $)$ & $\operatorname{PS}($ Mean \pm Sd) \\
\hline \multirow[t]{2}{*}{$\begin{array}{l}\text { Hospital type } \\
\text { studied }\end{array}$} & $\begin{array}{l}\text { University } \\
\text { Hospital }\end{array}$ & $\% 48.9$ & $32.17 \pm 5.2$ & $17.7 \pm 3.5$ & $24.8 \pm 3.7$ \\
\hline & $\begin{array}{l}\text { Education } \\
\text { Research } \\
\text { Hospital }\end{array}$ & $\% 51.1$ & $32.6 \pm 4.9$ & $18.1 \pm 3.8$ & $24.3 \pm 3.6$ \\
\hline \multicolumn{3}{|c|}{ Student $t(p$-value $)$} & $0.589^{b}$ & $0.658^{\mathrm{b}}$ & $0.552^{\mathrm{b}}$ \\
\hline \multirow[t]{5}{*}{$\begin{array}{l}\text { Education } \\
\text { Staff }\end{array}$} & $\begin{array}{l}1 \text { Faculty } \\
\text { Member }\end{array}$ & $\% 9.6$ & $33.4 \pm 5.5$ & $19.04 \pm 2.3$ & $25.8 \pm 2.8$ \\
\hline & $\begin{array}{l}2 \text { Faculty } \\
\text { Member }\end{array}$ & $\% 7.4$ & $33.2 \pm 4.2$ & $18.7 \pm 3.7$ & $25.38 \pm 3.8$ \\
\hline & $\begin{array}{l}3 \text { Faculty } \\
\text { Member }\end{array}$ & $\% 25.3$ & $31.2 \pm 4.1$ & $17.91 \pm 3.8$ & $24.5 \pm 3.7$ \\
\hline & $\begin{array}{l}4 \text { Faculty } \\
\text { Member }\end{array}$ & $\% 19.1$ & $30.7 \pm 4.6$ & $17.8 \pm 4.4$ & $23.4 \pm 3.6$ \\
\hline & $\begin{array}{l}5 \text { Faculty } \\
\text { Member }\end{array}$ & $\% 38.3$ & $28.6 \pm 4.3$ & $13.7 \pm 3.5$ & $21.8 \pm 2.3$ \\
\hline \multicolumn{3}{|c|}{ K.W.H.T(p value) } & $0.097^{\mathrm{b}}$ & $0.015^{\mathrm{a}}$ & $0.09^{\mathrm{a}}$ \\
\hline \multicolumn{6}{|c|}{$\begin{array}{l}\text { K.W.H.T.= Kruskal Wallis H Test, EE=Emotional Exhaustion,DS= Desensitization,PS=Personal Success } \\
\text { "a"=significance level of } p<0.05, " b "=>0.05 \text { is not significant. }\end{array}$} \\
\hline
\end{tabular}

When the 7 component of sleep quality was evaluated, the mean score of component 1 was 2.9 \pm 0.7 , component 2 mean was $2.96 \pm 0.9$, component 3 mean was $6 \pm 1.8$, component 4 mean was $0.6 \pm$ 1.3 , component 5 mean was $2 \pm 2.07$, component 6 mean was $0.2 \pm 0.7$, and component 7 mean was 2.1 \pm 1.13 . The total PSQI mean score of the participants in the study was $17.04 \pm 3.08$ (Table 4). 
Table 4. Average of the Sleep Quality Components of the Participants

\begin{tabular}{|r|c|}
\hline Sleep Quality Components & Mean \pm Sd \\
\hline Subjective Sleep Quality (Component 1) & $2.9 \pm 0.7$ \\
\hline Sleep Latency (Component 2) & $2.96 \pm 0.9$ \\
\hline Sleep Time (Component 3) & $6 \pm 1.8$ \\
\hline Conventional Sleep Activity (Component 4) & $0.6 \pm 1.3$ \\
\hline Sleep Disorder (Component 5) & $2 \pm 2.07$ \\
\hline Sleeping Drug Use (Component 6) & $0.2 \pm 0.7$ \\
\hline Daytime Dysfunction (Component 7) & $2.1 \pm 1.13$ \\
\hline The total PSQI mean score & $17.04 \pm 3.08$ \\
\hline
\end{tabular}

When PSQI mean scores were compared, there was no statistically significant difference between the socio-demographic characteristics of the participants in terms of age, marital status, number of children, and sex factors ( $\mathrm{p}>0.05$ ).

When the PSQI scores of the participants were evaluated according to the assistantship year and the year of work in the profession, there was no statistically significant difference ( $p>0.005)$. When the groups were evaluated according to their monthly working hours, there was a statistically significant difference in the PSQI score of the participants $\left(\chi^{2}: 8.223, \mathrm{p}=0.042\right)$.

When the PSQI score was evaluated according to the teaching staff of the participants in the study, there was no statistically significant difference between the groups $(p=0.084)$. When the groups were evaluated according to the type of hospital where the participants worked, there was no statistically significant difference $(\mathrm{p}=0.464)$. When grouped according to the number of daily patient admissions to the hospitals where they worked, there was a statistically significant difference between PSQI scores $(\mathrm{p}=0.044)$.

When the correlation between the MBI subgroups and the PSQI scoring was evaluated, a moderate positive correlation was found between emotional exhaustion and PSQI ( $\mathrm{p} \leq 0.001$ ). However, when the PSQI score was evaluated with the desensitization and personal success subgroups in the MBI, there was no positive or negative relationship ( $\mathrm{p}=0.103, \mathrm{p}=0.341$ ) (Table 5). When the sleep quality with MBI is evaluated by regression analysis, it is seen that the state of exhaustion affects the quality of sleep by $13.1 \%$. Especially emotional exhaustion has a positive significant correlation. $(\mathrm{P} \leq 0.001)$ As emotional exhaustion increases, sleep quality deteriorates. 
Table 5. Correlation of Sleep Quality with the MBI subgroups of the participants

\begin{tabular}{|c|c|c|}
\hline MBE Subgroups & Coerr.Coeff. & P-value \\
\hline Emotional exhaustion & 0.347 & $\leq 0.001^{*}$ \\
\hline Desensitization & 0.169 & 0.103 \\
\hline Personal Success & 0.099 & 0.341 \\
\hline * significance level of $\mathrm{p}<0.05$ & \multicolumn{2}{|l}{} \\
\hline
\end{tabular}

\section{Discussion}

Examining the burnout syndrome, which closely affects the lives of healthcare workers, is important in terms of preventing the problem [26]. The most important consequence of burnout is presented as the deterioration in the quality and quantity of the service provided, but it also causes serious physical and mental problems on individuals [27]. Emergency workers are constantly under stress due to critical patient care, work intensity, and the pace of work in shifts [28]. Among the factors that increase the burnout status during the emergency medicine assistant (EMA) training are long working hours and emergency patient density. However, sudden death cases cause instant mood changes. Stress factors increase and sleep disturbances occur due to the ongoing communication with other branches in patient admissions and consultation procedures.

It was reported that the burnout levels of gynecology and obstetric assistants performed in 2015 were $44 \%$, and in a different study conducted with emergency service employees in 2015, the burnout status was $57.1 \%$ [29,30]. According to the results of our study, burnout levels were found high with 92.6\% and they differed from the results of these studies. It is seen that EMAs with high burnout levels are not affected by variables such as sex and age whereas we see changes in desensitization and personal success scores as the number of children increase in the marital status and number of children groups. This situation gives rise to thoughts that EMAs, who have child responsibilities outside the hospital in their nonworking time, have decreased burnout due to the change in the areas of interests and socialization.

According to the results of our study, the scores of the MBI subgroups decrease as the year of work increases in the profession. Similar to our study, some studies have reported that burnout decreases as the working year increases [31,32]. According to these results, we believe that the physicians have a lack of experience in dealing with stressor factors in the first years of their career.

In the literature, in a study conducted with family doctor assistants, it was reported that burnout was higher in the first year assistant [33]. In another study conducted with plastic surgery assistants, it was reported that burnout status was high among first-year assistants [34].In our study, the difference between the groups was not statistically significant, although the MBI subgroups were high in 1st-year assistants. Unlike emergency medicine education, the number of duties decreases as the duration of education decreases in other assistant training. In emergency medicine assistantship, the work system of duties and shifts continues throughout the entire assistantship training. We believe that there is no difference between the years of education since EMAs continue to be dynamic from the 1st to the 4th year of the assistantship. 
In the study conducted by Esen et al. with family doctors, it was reported that the burnout levels increased as the working hours increased [3]. Similarly, in our study, as the monthly working hours increase, the level of burnout increases. These results suggest that due to the increase in working hours, the level of burnout increases as the time allocated for themselves decreases. Ersoy et al. in their study with EMAs, reported that burnout levels differed according to the type of hospital worked at [35]. In our study, unlike theirs, burnout levels do not differ according to the type of hospital. In addition, when the burnout levels are evaluated according to the training staff in the studied hospital, the desensitization in their subgroups decreases as the training staff increases, however, the personal accomplishment subgroup scores increase as the training staff increases. It was concluded that the high number of training staff increased the personal accomplishment and confidence of EMAs while decreasing desensitization, and that receiving training in their intensive emergency service working life improved motivation.

It was concluded that $100 \%$ of EMAs participating in the study had poor sleep quality according to their PSQI scores. In a study conducted in the literature, daytime healthcare workers were found to have better sleep quality than shift workers [36]. In other studies conducted in the literature, it was reported that sleep quality was negatively affected in the work system with shifts and duties $[37,38,39]$. The results obtained in our study were similar to the data in the literature, and it was concluded that, due to the principle of working with shifts or 24-hour duties in emergency departments, EMA experienced disrupted circadian sleep rhythms in this work pattern.

In our study, unlike previous studies, sleep quality is not affected by factors of sex, marital status, and the number of children [40,41]. We think that the sleep quality is poor in the profession and emergency medicine training since its beginning and this situation does not change over the years, because the poor sleep quality starts to occur during the medical school years in the difficult training period. The increase in monthly working hours worsens sleep quality. It is observed that the quality of sleep is impaired in the places where the number of patients in the hospitals, where EMAs work, is high. In our opinion, this results from the fact that the pre-duty stress factors increased due to the previous experiences of EMAs, and their sleep quality deteriorated.

According to the results of our study, sleep quality deteriorates as emotional exhaustion increases. This supports the results obtained in previous studies $[42,43]$. However, the difference between these studies and ours is the presence of no correlation between desensitization and sleep quality in our study. As the reason for this difference, it was concluded that the participants experienced different emotions due to the difference in the profession group and sample of the studies. Emotional exhaustion from the burnout inventory affects the quality of sleep at the level of $13.1 \%$. Especially when emotional exhaustion increases, it is seen that sleep quality will also be affected badly.

Limitation in our study; Burnout syndrome can be affected by many factors. The limitation of our study is that we do not question the chronic diseases of the participants' socio-demographic characteristics.

\section{Conclusion and Recommendations}

A high level of burnout during the training period of the emergency medicine assistants causes sleep quality deterioration. This causes difficulties in work and private lives over time. The increase in monthly working hours and the difference in social lives increase burnout and sleep quality impairment. The low number of training staff reduces the sense of personal accomplishment and 
increases desensitization. We think that it will be beneficial to regulate the monthly working hours in order to decrease the burnout levels and increase sleep quality for keeping EMAs physically and mentally healthy, to increase the number of the training staff to make them feel safe, and to organize programs to increase non-work social activities.

\section{Ethics declaration}

This study was approved by the Ethics Committee of Yozgat Bozok University on 30.10.2019 with the decision of 2017-KAEK-189_2919.189.10.30_24.

The study was carried out in accordance with the Helsinki Declaration. The study is voluntary and permission has been obtained from the participants.

The compliance to the Research and Publication Ethics: This study was carried out in accordance with the rules of research and publication ethics.

\section{References}

[1] Maslach, C., Schaufeli, W., Leiter, M, "Job burnout. In: Fiske S, Schacter D, Zahn-Waxler C, editors", Annu Rev Psychol, 52, 397-422. 2001.

[2] Freudenberger, H.J., "Staff Burn-Out”, Journal of Social Issues, 30 (1), 159-165,1974.

[3] Esen, A.D., Mercan, G.N., Ezgi, K.E., "Aile Hekimliği Asistanlarında Tükenmişlik Sendromu", Anatol JFM, 1, 34-36, 2018.

[4] Arıkan, F., Gokce, C., Ozer, Z.C. et al "Tukenmislik ve Hemsirelik" Hemsirelik Forumu 2, 14$17,2006$.

[5] Canbaz, S., Sunter, T., Dabak, S et al. "Hemsirelerde Tukenmislik Sendromu, İs Doyumu ve İse Bağlı Gerginlik" Hemsirelik Forumu, 4,30-34, 2005.

[6] Butterfield, PS. "The Stress of Residency. A Review of the Literature”, Arch Intern Med, 148(6),1428-35,1988.

[7] Vanttola, P., Härmä, M., Viitasalo, K., Hublin, C., Virkkala, J., Sallinen, M., "Puttonen S. Sleep and alertness in shift work disorder: findings of a field study", International Archives of Occupational and Environmental Health, 92(4), 523-533, 2019.

[8] Kawada, T., Suzuki, S., "Monitoring sleep hours using a sleep diary and errors in rotating shiftworkers", Psychiatry Clin Neurosci, 56,213-4, 2002.

[9] Grandner, M.A., "Sleep, health, and society”, Sleep Med Clin., 12, 1-22, 2017.

[10] Schwab, R.J., Goldberg, A.N., Pack, A.L., "Sleep apnea syndromes" In Fishman AP, editor. Fishman's Pulmonary Diseases and Disorders. New York: McGraw - Hill Book Company, 1617-37, 1998.

[11] Ekstedt, M., Söderström, M., Akerstedt, T., "Sleep physiology in recovery from burnout", Biological Psychology, 82(4), 267-73. 2009.

[12] Smith, L, Tanigawa, T., Takahashi, M., "Shiftwork locus of control, situational and behavioural effects on sleepiness and fatigue in shiftworkers", Industrial Health, 43(2),

151-70, 2005. 
[13] Keskin, M.T., Kubilay, G., "Özel bir hastanede çalışan hemşirelerin yaşam alışkanlıkları ve çalışma koşullarından kaynaklı sağlık sorunlarının değerlendirilmesi”, Hacettepe Üniversitesi Hemşirelik Fakültesi Dergisi, 18(1),41-49, 2011.

[14] Demir, H.P., Elkin, N., Barut, A.Y., Bayram, H.M., Averi, S., "Vardiyalı Çalışan Sağlık Personelinin Uyku Süresi ve Beslenme Durumunun Değerlendirilmesi”, IGUSABDER, 2, 89107, 2017.

[15] Shen, J., Botly, L.C.P., Chung, S.A., "Fatigue and shift work", Journal of Sleep Research, 15(1), 1-5, 2006.

[16] Sönmez, S., Ursavaş, A., Uzaslan, E., "Vardiyalı çalışan hemşirelerde horlama, uyku bozuklukları ve iş kazaları”, Türk Toraks Dergisi, 11(2), 105-8, 2010.

[17] Dogan, S.D., Arslan, S., Aydıngulu, N., Koparan, H., Gulsen, M., "Sleep quality of nurses working with shift system",Cukurova Med J., 44(4),1196-1202, 2019.

[18] Arabacı, L.B., Korhan, E.A., Tokem, Y., Torun, R., "Hemşirelik birinci sınıf öğrencilerinin ilk klinik deneyim öncesi-sırası ve sonrası anksiyete ve stres düzeyleri ve etkileyen faktörler" Hacettepe Üniversitesi Hemşirelik Fakültesi Dergisi, 2(1),1-16,2015.

[19] Cañadas-De la Fuente, G.A., Vargas, C., San Luis, C., García, .I, Cañadas, G.R., Emilia, I., "Risk factors and prevalence of burnout syndrome in the nursing profession", International Journal of Nursing Studies, 52(1), 240-249, 2015.

[20] URL https://istatistik.yok.gov.tr/ (Access date: 01.02.2020), 2020.

[21] Maslach, C., Jackson, S.E., "The measurement of experienced burnout”, J Organ Behav, 2(2), 99-113, 1981.

[22] Ergin, C., "Doktor ve hemsirelerde tukenmislik ve Maslach tukenmislik olceginin uyarlanmasi", VII Ulusal Psikoloji Kongresi, 22nd September 1992, Ankara (Turkey).

[23] Buysse, D.J., et al. "Relationships Between the Pittsburgh Sleep Quality Index (PSQI), Epworth Sleepiness Scale (ESS) and Clinical/Polysomnographic Measures in a Community Sample", $J$ Clin Sleep Med, 4,563-71, 2008.

[24] Buysse, D.J., Charles, F., Reynolds, C.F., "The pittsburgh sleep quality index: A new instrument for psychiatric practice and research”, Psychiatry Research, 28(7), 193-213, 1989.

[25] Ağargün, M.Y., Kara, H., Anlar, Ö., "Pittsburgh uyku kalitesi indeksi’nin geçerliliği ve güvenirliliŭgi”, Türk Psikiyatri Dergisi, 7(2), 107-15, 1996.

[26] Turgut, N., Karacalar, S., Polat, C., Kıran, Ö., Gültop, F., Kalyon, S.T., Sinoğlu, B., Zincirci, M., Kaya, E., "Burnout Syndrome During Residency", Turk J Anaesthesiol Reanim, 44, 258-64, 2016.

[27] Taycan, O., Kutlu, L., Çimen, S., Aydın, N., "Bir üniversite hastanesinde çalışan hemşirelerde depresyon ve tükenmişlik düzeyinin sosyodemografik özelliklerle ilişkisi”, Anadolu Psikiyatri Dergisi, 7, 100-8, 2006. 
[28] Popa, F., Arafat, R., Purcărea, V.L., Lală, A., Popa-Velea, O., Bobirnac, G., “Occupational Burnout levels in Emergency Medicine-a stage 2 nationwide study and analysis" J Med Life, 3(4), 449-453, 2010.

[29] Moradi, Y., Baradaran, H.R., Yazdandoost, M., Atrak, S., Kashanian, M., "Prevalence of Burnout in residents of obstetrics and gynecology: A systematic review and meta-analysis", Med J Islam Repub Iran, 29, 235, 2015.

[30] Lu, D.W., Dresden, S., McCloskey, C., Branzetti, J., Gisondi, M.A., "Impact of Burnout on Self-Reported Patient Care Among Emergency Physicians”, West J Emerg Med, 16, 996-1001, 2015.

[31] Turgut, N., Karacalar, S., Polat, C., et al. "Burnout Syndrome During Residency", Turkish Journal of Anaesthesiology and Reanimation, 44(5), 258-64, 2016.

[32] An1l, M., Yurtseven, A., Yurtseven, İ., et al. "The evaluation of burnout and job satisfaction levels in residents of pediatrics”, Turkish Archives of Pediatrics, 52(2), 66-71, 2017.

[33] Rendon-Sanchez, J.L., Ramirez-Leyva, D.H., BermudezVillalpando, V.I., Camacho-Romo, J.J., Grajeda- Gonzalez, L.B., Ramirez-Leyva, P.H., "Depression, Anxiety and Burnout Syndrome in Medical Residents of Family Medicine in Tijuana, Mexico", J Fam Med, 4(6), 1131, 2017.

[34] Chaput, B., Bertheuil, N., Jacques. J., Smilevitch, D., Bekara, F., Soler, P., et al. "Professional burnout among plastic surgery residents: can it be prevented? outcomes of a national survey", Ann Plast Surg, 75, 2-8, 2015.

[35] Ersoy, S., Kavalc1, C., Yel, C., Yılmaz, F., Kavalc1, G., Aslan, Ö., "Tıp Fakültesi Hastaneleri ve Sağlık Bakanlığı Eğitim ve Araştırma Hastanelerinde Çalışan Acil Tıp Asistanlarının Tükenmişlik Düzeylerinin Karşılaştırılması”, Ankara Med J., 14(2), 41-45, 2014.

[36] Bumin, G., Tatl1, I.Y., Cemali, M., Kara, S., Akyürek, G., "The Comparison of the Quality of Sleep, Stress, Well-being and Reaction Time Among Health Care Professionals with Shift and Day Workers", Huhemfad-Johufon, 6(3),170-176, 2019.

[37] Çetinol, T., Özvurmaz, S., "Hemşirelerde Uyku Kalitesi ve İlişkili Faktörler", Medical Sciences, 13(4), 80-89, 2018.

[38] Tarhan, M., Aydin, A., Ersoy, E., Dalar, L., “The sleep quality of nurses and its influencing factors", Eurasian Journal of Pulmonology, 20(2), 78-84, 2018.

[39] Gómez-García, T., Ruzafa-Martínez, M., Fuentelsaz-Gallego, C., Madrid, J.A., Rol, M.A., Martínez-Madrid, M.J., Moreno-Casbas, T., "Nurses' sleep quality, work environment and quality of care in the Spanish National Health System: an observational study among different shifts", BMJ Open, 6(8),1-11, 2016.

[40] Çoban, S., Yılmaz, H., Ok, G., Erbüyün, K., Aydın, D., "Yoğun bakım hemşirelerinde uyku bozukluklarının araştırılması", Türk Yoğun Bakım Derneği Dergisi, 9(1), 59-63, 2011.

[41] Luz, E.M.S., Marqueze, E., Moreno, C., "Job satisfaction and sleep quality in nursing professionals", Sleep Science, 4(2), 49-51, 2011. 
[42] Şentürk, S., "Evaluation of the Relationship Between Burnout Levels and Sleep Quality in the Intensive Care Unit Nurses”, Bozok Med J, 4(3),48-56, 2014.

[43] Demir, Z.A., Arslan, S., "Morning-evening type and burnout level as factors influencing sleep quality of shift nurses: a questionnaire study", Croatian Medical Journal., 52(8), 527-37, 2011. 